\title{
Constitutive and Inducible Expression of HLA Class II Determinants by Human Osteoblast-like Cells In Vitro
}

\author{
Henrik Skjødt, * David E. Hughes, Pauline R. M. Dobson, and R. Graham G. Russell \\ *Departments of Medicine and Pathology, Sundby Hospital, DK-2300 Copenhagen S, Denmark; and Department of Human \\ Metabolism and Clinical Biochemistry, University of Sheffield Medical School, Sheffield S10 2RX, United Kingdom
}

\begin{abstract}
Activated immune cells release cytokines which modulate the activity of bone cells in vitro. Expression of major histocompatibility complex (HLA in humans) class II determinants on bone surface cells may be important in local immune cell activation. In this study, expression of HLA-DR and DQ by cultured human bone cells (HBC) derived from normal trabecular bone surfaces was assessed by fluorescence-activated cell sorter (FACS) analysis and immunoperoxidase techniques using monoclonal antibodies. A subset of HBC (10-30\%) expressed DR constitutively while 5-15\% displayed DQ during long-term culture. HBC lacked a number of monocyte and lymphocyte markers. In addition, both $\mathrm{DR}^{+}$and $\mathrm{DR}^{-} \mathrm{HBC}$ (FACS separated) produced osteocalcin stimulated by 1,25-dihydroxyvitamin $D_{2}\left(1,25(O H)_{2} D_{3}\right)$. This suggests that both phenotypes belong to the osteoblast lineage. The number of $\mathrm{DR}^{+} \mathrm{HBC}$ was increased by interferon-gamma (IFN $\gamma ; 40-95 \%$ $\mathrm{DR}^{+}$cells) whereas $\mathrm{DQ}^{+} \mathrm{HBC}$ remained unchanged or was slightly increased (5-20\% $\mathrm{DQ}^{+}$cells). Moreover, $1,25(\mathrm{OH})_{2} \mathrm{D}_{3}$ enhanced IFN $\gamma$-induced DR expression and at high concentration $\left(10^{-7} \mathrm{M}\right)$ augmented DR expression by itself. Other major osteotropic factors, parathyroid hormone, interleukin 1 , and calcitonin, did not affect HBC DR expression. The findings suggest that $\mathrm{HBC}$ may participate in activation of the immune system and that some osteotropic factors may regulate this function. (J. Clin. Invest. 1990. 85:1421-1426.) osteoblasts $\bullet$ HLA class II $\bullet$ interferon- $\gamma \cdot 1,25$-dihydroxyvita$\min D_{3}$
\end{abstract}

\section{Introduction}

Immune cells including macrophages and lymphocytes present at the bone remodeling site may regulate bone resorption (reviewed by Vaes [1]). For example, interleukin 1 (IL-1) is the major osteoclast-activating cytokine produced by normal activated peripheral blood leukocytes (2). Tumor necrosis factor-

This work was presented in part at the First International Workshop on Cells and Cytokines in Bone and Cartilage, Davos, Switzerland, December 1985 and was published as an abstract (1985. Calcif. Tissue Int. 38:S28).

Address reprint requests to Dr. Skjødt, Department of Medicine, Sundby Hospital, Italiensvej 1, DK-2300 Copenhagen S, Denmark.

Received for publication 15 September 1989 and in revised form 20 December 1989.

1. Abbreviations used in this paper: EMEM, Eagle's modified MEM; HBC, human bone cell(s); NK, natural killer (cell); TBS, Tris-buffered saline; TNF, tumor necrosis factor.

J. Clin. Invest.

(c) The American Society for Clinical Investigation, Inc.

0021-9738/90/05/1421/06 \$2.00

Volume 85, May 1990, 1421-1426 alpha (TNF $\alpha)^{1}$ produced by macrophages and the T lymphocyte-cytokine tumor necrosis factor-beta $(\mathrm{TNF} \beta)$ also have bone-resorbing activity in vitro (3). These cytokines may stimulate osteoclast precursors (4). In addition, osteoblasts are stimulated by IL- $1, \mathrm{TNF} \alpha$, and TNF $\beta$ to release factors or mediate direct cell-cell membrane interactions activating osteoclastic bone resorption in vitro $(5,6)$. By contrast, interferon-gamma (IFN $\gamma$ ), released by activated $\mathrm{T}$ lymphocytes, inhibits immune cytokine (IL-1, TNF $\alpha$, and TNF $\beta$ )-stimulated bone resorption in vitro (7). These findings suggest that activated immune cells could be involved in bone resorption by release of cytokines regulating the osteoclast lineage directly and/or through osteoblasts.

Factors that might direct immune cell activation at the remodeling site are unknown. An immune response, however, involves $T$ lymphocyte recognition of antigen displayed on the surface of antigen-presenting cells (APC) in the context of a HLA class II molecule (for a review see Royer and Reinherz [8]). As a consequence of this HLA class II-dependent T cell activation, a number of proteins are synthesized, including osteotropic cytokines (9). Thus, presence of HLA class II-positive cells at the bone remodeling site may be essential for immune cell activation and local release of osteoclast-regulating cytokines.

We examined the expression of HLA class II determinants (DR and DQ) on human osteoblast-like bone cells (HBC) derived from normal trabecular bone surfaces in vitro. Moreover, regulation of HBC HLA class II expression by osteotropic factors were studied, including $1,25(\mathrm{OH})_{2} \mathrm{D}_{3}$, parathyroid hormone (PTH), calcitonin, purified human IL-1, and recombinant human IFN $\gamma$ (rIFN $\gamma$, a known inducer of class II major histocompatibility complex molecules in a variety of immune and nonimmune cells [10]). We demonstrate that $(a)$ a subset of HBC expresses DR and DQ constitutively and $(b)$ HBC DR expression is enhanced by $\operatorname{rIFN} \gamma$ and $1,25(\mathrm{OH})_{2} \mathrm{D}_{3}$.

\section{Methods}

Patients. Bone specimens (surgical discards) were obtained from 20 patients 32-81 yr old (median age $66 \mathrm{yr} ; 14$ female and 6 male) undergoing corrective surgery after fractures or femoral amputation because of vascular insufficiency (representative details of 10 patients in Table I). None of the patients showed signs of bone or joint disease or immune disorders.

Bone preparation and cell culture. Human trabecular bone sections were isolated and dissected into $0.3-0.5-\mathrm{cm}$ fragments as described (11). The fragments were washed vigorously in phosphate-buffered saline (PBS, pH 7.4) to remove marrow, seeded onto 9-cm plastic culture dishes (Falcon Labware, Oxford, UK) and cultured in Eagle's modified minimum essential medium (EMEM) containing $10 \mathrm{mM}$ Hepes buffer, $10 \%$ fetal calf serum (FCS; heat-inactivated), $2 \mathrm{mM}$ L-glutamine, $50 \mu \mathrm{g} / \mathrm{ml}$ ascorbate, $50 \mathrm{U} / \mathrm{ml}$ penicillin, and $150 \mu \mathrm{g} / \mathrm{ml}$ streptomycin. All cell culture products were from Gibco Laboratories (Paisley, Scotland) and chemicals from Sigma Chemical Co. (Poole, Dorset, UK) unless otherwise stated. Cultures were kept at $37^{\circ} \mathrm{C}$ in a 


\begin{tabular}{|c|c|c|c|c|c|c|c|c|c|}
\hline \multirow[b]{3}{*}{ Donor } & \multirow[b]{3}{*}{ Length of culture } & \multicolumn{6}{|c|}{$\mathrm{DR}^{+}$cells } & & \\
\hline & & \multicolumn{2}{|c|}{ HLA-DR } & \multicolumn{2}{|c|}{12} & \multicolumn{2}{|c|}{ DAKO-HLA-DR } & \multicolumn{2}{|c|}{$\mathrm{DQ}^{+}$cells Leu-10 } \\
\hline & & FACS & IP & FACS & IP & FACS & IP & FACS & IP \\
\hline & $w k$ & \multicolumn{8}{|c|}{$\%$} \\
\hline 1 & 5 & 26 & 23 & 23 & 23 & ND & ND & 9 & 8 \\
\hline 2 & 11 & 14 & 15 & 12 & 13 & ND & ND & 5 & 5 \\
\hline 3 & 7 & 10 & ND & 13 & ND & ND & ND & 7 & ND \\
\hline 4 & $21^{*}$ & 24 & 24 & 22 & 21 & 26 & 25 & 15 & 13 \\
\hline 5 & 14 & 30 & 28 & 25 & 29 & 30 & 29 & 9 & 9 \\
\hline 6 & $25^{*}$ & 12 & 12 & 14 & ND & ND & ND & 5 & 6 \\
\hline 7 & 6 & 18 & 19 & 20 & 20 & 16 & ND & 9 & 9 \\
\hline 8 & 6 & 16 & ND & ND & ND & ND & ND & 8 & 9 \\
\hline 9 & 13 & 13 & 12 & 18 & 14 & 19 & 18 & 10 & 8 \\
\hline 10 & 9 & 14 & 14 & 11 & 13 & 16 & ND & 13 & ND \\
\hline
\end{tabular}

Details of Patients

\begin{tabular}{cclll}
\hline Donor & Male (M)/female (F) & Age & \multicolumn{1}{c}{ Diagnosis } & Origin of explants \\
\hline & & $y r$ & & Femoral condyles \\
1 & M & 32 & Fracture (amputation) & Femoral head \\
2 & F & 78 & Fracture & Femoral head \\
3 & F & 69 & Fracture & Distal tibia \\
5 & M & 59 & Ischemia (amputation) & Femoral head \\
6 & F & 71 & Fracture & Femoral condyles \\
7 & M & 70 & Ischemia (amputation) & Femoral head \\
8 & F & 64 & Fracture & Femoral head \\
9 & F & 81 & Fracture & Femoral head \\
10 & F & 62 & Fracture & Femoral head
\end{tabular}

First-passage $\mathrm{HBC} .{ }^{*} \mathrm{HBC}$ cultures 4 and 6 reexamined at monthly intervals (2-6 mo) showed a stable percentage of DR-and DQ-positive cells (data not shown). IP, immunoperoxidase staining; ND, not determined.

humidified atmosphere of $95 \%$ air, $5 \% \mathrm{CO}_{2}$ and after an initial replacement at $24 \mathrm{~h}$, medium was changed once weekly. Cell outgrowth was seen within $7 \mathrm{~d}$ and confluent monolayers obtained after 3-6 wk. At confluence, cells were detached by brief exposure $\left(<5 \mathrm{~min}\right.$ at $\left.37^{\circ} \mathrm{C}\right)$ to trypsin/EDTA ( 0.5 and $0.2 \mathrm{~g} /$ liter, respectively), replated into $9-\mathrm{cm}$ culture dishes, 3.5 -cm multiwell trays, or eight chamber tissue culture glass slides (Lab-Tek Division, Miles Laboratories, Slough, UK) at 5 $\times 10^{3}$ cells $/ \mathrm{cm}^{2}$, and cultured in complete EMEM. Viability (eosin exclusion) exceeded $95 \%$. Experiments were commenced $24 \mathrm{~h}$ after first passage. All cultures contained cells which expressed an osteoblast-like phenotype in terms of $1,25(\mathrm{OH})_{2} \mathrm{D}_{3}$-stimulated osteocalcin production. After exposure to $10^{-9} \mathrm{M} 1,25(\mathrm{OH})_{2} \mathrm{D}_{3}$ for $48 \mathrm{~h}, \geq 95 \%$ of the cells stained positively for osteocalcin using a specific antibody (DAKOPATTS, Glostrup, Denmark) and immunoperoxidase techniques.

Reagents. A panel of murine anti-human monoclonal antibodies (MAbs) was used: four MAbs reacting with HLA class II epitopesHLA-DR and 12 directed at monomorphic DR antigens, Leu-10 reacting with polymorphic DQ epitopes, and DAKO-HLA-DR detecting polymorphic DR and DQ (except DQw10); Leu-M3 detecting cells of the monocyte/macrophage lineage; Leu-1 (pan-T lymphocyte reagent, CD5 [CD, cluster of differentiation antigen]); Leu-14 (B lymphocytes, CD22); and Leu-11 (natural killer [NK] cells, CD16). The MAbs were used in concentrations titrated to be saturating on $\mathrm{HBC}$ or positive controls (peripheral blood mononuclear cells). Antibodies were purchased from Becton, Dickinson Ltd., Laboratory Impex,
Middlesex, UK, except DAKO-HLA-DR (DAKOPATTS) and I2 (Coulter Immunology, Hialeah, FL).

Phagocytic activity was determined by addition of latex beads (1.091- $\mu \mathrm{m}$ diameter, Sigma Chemical Co. $)$ to $\mathrm{HBC}\left(2 \times 10^{6}\right.$ cells in 0.2 $\mathrm{ml}$ of EMEM) at a cell/particle ratio of $1: 100$, sedimentation at $50 \mathrm{~g}$ for $5 \mathrm{~min}\left(20^{\circ} \mathrm{C}\right)$, and incubation at $37^{\circ} \mathrm{C}$ for $1 \mathrm{~h}$. Cells were then washed three times to remove free latex and examined by phase-contrast microscopy.

Nonspecific esterase staining with alpha-naphthyl butyrate as substrate (12) was performed by means of a Sigma Chemical Co. kit.

In some experiments, cycloheximide $(20 \mu \mathrm{g} / \mathrm{ml}$, Sigma Chemical Co.) was added to $\mathrm{HBC}$ cultures to examine the effect of inhibition of protein synthesis on the inducible expression of HLA-DR.

Since reagents might contain low levels of endotoxin, polymyxin B ( $5 \mu \mathrm{g} / \mathrm{ml}$, Sigma Chemical Co.) was added in some experiments to evaluate the effect of endotoxin inhibition (13).

Effect of osteotropic factors on HBC HLA class II expression. Human rIFN $\gamma$ (Amgen Co., Thousand Oaks, CA 91320; kindly provided by Dr. R. C. Rees, Department of Virology, University of Sheffield Medical School), human purified IL-1 (Lot N101; a generous gift of Dr. C. A. Dinarello, New England Medical Center, Boston, MA), $1,25(\mathrm{OH})_{2} \mathrm{D}_{3}$ (kindly supplied by Dr. M. R. Uskovics, Hoffman LaRoche Co., Nutley, NJ), purified bovine PTH 1-84 fragment (from the National Institutes for Biological Standards and Control, South Mimms, UK), and salmon calcitonin (obtained from Armour Pharmaceutical Co., East Sussex, UK) were added to cultures (duplicate 
3.5-cm multiwells or chamber slides) for $48 \mathrm{~h}$. During experiments medium was changed daily. After culture, $3.5-\mathrm{cm}$ wells were trypsinized, washed three times (EMEM, $4^{\circ} \mathrm{C}$ ), kept in suspension by gentle stirring in EMEM with $1 \%$ bovine serum albumin (BSA) for $4-6 \mathrm{~h}$ (at $37^{\circ} \mathrm{C}$ in a $95 \%$ air, $5 \% \mathrm{CO}_{2}$ incubator), and then aliquotted at $5 \times 10^{5}$ cells per sample for fluorescence-activated cell sorter (FACS) analysis. Chamber slides were examined also by immunoperoxidase staining.

FACS analysis. All reagents were diluted in EMEM with $0.1 \%$ BSA and $0.02 \%$ sodium azide. For indirect immunofluorescence, saturating concentrations of the desired MAb were added to HBC $\left(5 \times 10^{5}\right.$ cells incubated at $4^{\circ} \mathrm{C}$ for $30 \mathrm{~min}$ ). Controls were stained with an isotypespecific MAb of irrelevant specificity. After washing twice in PBS, fluorescein isothiocyanate (FITC)-conjugated goat anti-mouse IgG (Tago Inc., Tissue Culture Service, Slough, Berkshire, UK) was added as a second layer $\left(30 \mathrm{~min}, 4^{\circ} \mathrm{C}\right)$. The cells were then washed three times in PBS and kept on ice in a PBS/0.1\% BSA solution. Immediately before analysis, samples were agitated and gently passed through a 27-gauge needle to avoid settling and aggregation. A FACS 420 (Becton, Dickinson Ltd.) was used for analysis of fluorescent cells (14) based on a reading of 10,000 viable cells per sample gated on the basis of propidium iodide exclusion (viability $>95 \%$ ). Percent positive cells was calculated by integration of area under the curve upon subtraction of the respective control background. The mean fluorescence intensity was measured by the median channel. In all experiments, a constant setting of the FACS (gain, amplifier, and photomultiplier voltage) was maintained. Membrane marker-positive cells were evaluated in parallel with fluorescence microscopy and immunoperoxidase staining.

Immunoperoxidase staining. After washing in PBS, HBC duplicate chamber slide cultures were fixed for $30 \mathrm{~s}$ in a phosphate-buffered acetone/formaldehyde fixative. Slides were rinsed in $0.2 \mathrm{M}$ Tris-buffered saline (TBS), $\mathrm{pH}$ 7.6, and air-dried. To inactivate any endogenous peroxidase activity slides were treated with $3 \% \mathrm{H}_{2} \mathrm{O}_{2}$ in TBS for $5 \mathrm{~min}$ at room temperature and rinsed well with buffer. Nonimmune rabbit serum (10\%, Wellcome, Kent, UK) in PBS was added, and slides were incubated for $20 \mathrm{~min}$ at room temperature. The rabbit serum was tapped off and then, without rinsing, $20 \mu \mathrm{l}$ of MAb, titrated to establish a low concentration still effective for staining, was added in a TBS $/ 0.1 \%$ BSA solution, and slides were incubated for $30 \mathrm{~min}$ at room temperature followed by a wash in TBS. Peroxidase-conjugated rabbit anti-mouse IgG (DAKOPATTS; $20 \mu$ l diluted $1: 50$ in TBS $/ 0.1 \%$ BSA) was added, slides were incubated for $30 \mathrm{~min}$ at room temperature, and rinsed with TBS. Finally, $20 \mu \mathrm{l}$ of a 3'3 diamino-benzidine (Sigma Chemical Co., grade II) solution ( $6 \mathrm{mg}$ in $10 \mathrm{ml}$ of $0.2 \mathrm{M}$ Tris buffer, $\mathrm{pH} 7.6$, containing $0.1 \%$ hydrogen peroxide) was added, and slides were incubated for $10 \mathrm{~min}$ at room temperature, rinsed, hematoxylincounterstained, and mounted with coverslips. In all experiments, $>400$ cells were counted for each duplicate sample.

Cell sorting. HBC were sorted on the basis of HLA-DR epitope density. Samples of $2 \times 10^{7}$ cells were detached from 9-cm plates (1-2 $\times 10^{6}$ cells per plate) and prepared for indirect immunofluorescence using the MAb HLA-DR. Using the FACS 420 under sterile conditions, cells were separated into a cell fraction with high-density DR epitope expression (cutoff point was chosen at fluorescence intensity channel 60 , gating channel $61-254 ;>95 \% \mathrm{DR}^{+}$), and a cell fraction with low-density DR expression (gating channel $1-60 ;<5 \% \mathrm{DR}^{+}$). After sorting, the recovered cell populations were washed twice, plated into $3.5-\mathrm{cm}$ multiwell trays at $5 \times 10^{3} \mathrm{cells} / \mathrm{cm}^{2}$, and cultured in complete EMEM. The purity of the sorted cells was determined by reanalysing aliquots of the sorted subsets on the FACS 420 immediately after sorting. After a 48 -h recovery period the cells were assayed for $1,25(\mathrm{OH})_{2} \mathrm{D}_{3}$-stimulated osteocalcin production.

Assay of osteocalcin. Osteocalcin was measured by radioimmunoassay as described previously (11). The antibody used was raised in rabbits to purified osteocalcin isolated from calf bone.

Statistical analysis. Significant differences were compared by Student's $t$ test. Data are expressed as the average of replicates (mean \pm SEM).

\section{Results}

$H B C$ express $H L A-D R$ and $D Q$ constitutively in long-term culture. Examined at first passage, $\mathrm{HBC}$ had the appearance of homogeneous elongated, generally bipolar, adherent fibroblast-like cells. When HBC were studied by using anti-HLADR and -DQ MAbs, many cells showed a stable expression of these HLA class II determinants even after several months of culture. Table I shows the percentage of $\mathrm{HBC}$ positive for the various anti-HLA class II reagents in 10 representative cultures. No difference was found between results using monomorphic and polymorphic anti-DR MAbs. The mean values for all cultures $(n=20)$ were $15.2 \% \mathrm{DR}^{+}$(MAb HLA-DR) $\mathrm{HBC}$ (range $10-30 \%$ ) and $8.5 \% \mathrm{DQ}^{+}$(MAb Leu-10) $\mathrm{HBC}$ (range 5-15\%). The possibility that the trypsin/EDTA treatment necessary for preparation of single cell suspensions for FACS analysis might change HLA class II expression was excluded (Table I shows no significant differences between cells stained on chamber slides without enzymatic treatment [immunoperoxidase] and the stained single cell suspension [FACS]). In all cultures, $\mathrm{DR}^{+} \mathrm{HBC}$ exceeded $\mathrm{DQ}^{+} \mathrm{HBC}$ in terms of cells numbers and staining intensity as documented by FACS analysis (Fig. 1 illustrates results from two representative cultures). To evaluate the effect of endotoxin that might contaminate reagents, polymyxin B was added into two cultures with and without bacterial LPS $(0.5 \mu \mathrm{g} / \mathrm{ml}$, Sigma Chemical Co.) for a 48-h incubation period. No change of HLA-DR and -DQ expression was found (data not shown).

HBC lack a panel of immune cell markers. Since hemopoietic marrow cells, such as monocyte/macrophages and lymphocytes, might be present in the HBC cultures possibly affecting HLA class II expression, some immune cell markers were examined (Table II). None of the cells showed phagocytic activity as determined by latex ingestion. A faint staining for nonspecific esterase in all HBC (previously described in a similar cell system [15]) contrasted with the bright membrane

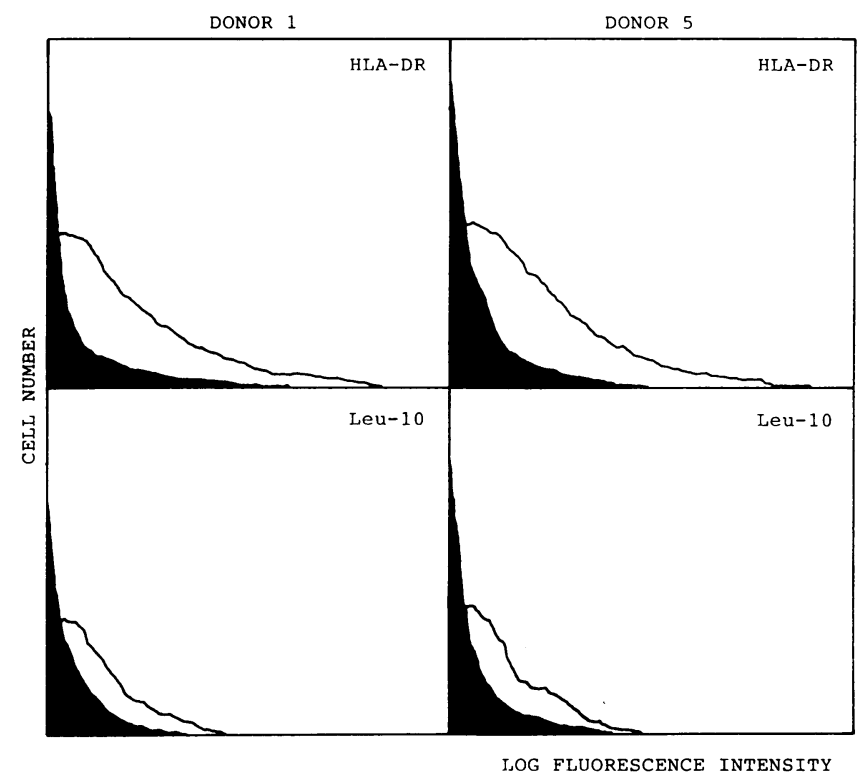

Figure 1. FACS analysis illustrating the distribution of HLA-DRand HLA-DQ-positive HBC from two donors. (Black area) Background staining with MAb of irrelevant specificity; (curve) DR- and DQ-positive cells. HLA-DR, MAb HLA-DR; Leu-10, MAb Leu-10. 
Table II. HBC Examined for Immune Cell Markers

\begin{tabular}{|c|c|c|}
\hline Marker & Positive cells & $n$ \\
\hline & $\%$ & \\
\hline \multicolumn{3}{|l|}{$\mathbf{M} \phi$} \\
\hline$\alpha$-Naphthyl butyrate esterase & 100 (weak staining) & 9 \\
\hline Latex ingestion & 0 & 8 \\
\hline MAb Leu-M3 & 0 & 15 \\
\hline \multicolumn{3}{|l|}{ T lymphocytes } \\
\hline MAb Leu-1 (CD5) & 0 & 15 \\
\hline \multicolumn{3}{|l|}{ B lymphocytes } \\
\hline MAb Leu-14 (CD22) & 0 & 15 \\
\hline \multicolumn{3}{|l|}{ NK cells } \\
\hline MAb Leu-11 (CD16) & 0 & 15 \\
\hline
\end{tabular}

First-passage HBC. $n$, number of cultures analyzed; MAb staining assessed by FACS analysis, immunofluorescence microscopy, and immunoperoxidase microscopy; $\mathrm{CD}$, cluster of differentiation.

staining of peripheral blood monocytes. In addition, membrane markers of monocyte/macrophages, $\mathrm{T}$ and $\mathrm{B}$ lymphocytes, and NK cells determined by using MAbs were negative.

Sorted $\mathrm{DR}^{+}$and $\mathrm{DR}^{-} \mathrm{HBC}$ both produce osteocalcin. In order to investigate the possible presence of an osteoblast marker, osteocalcin (16), on the $\mathrm{DR}^{+}$and $\mathrm{DR}^{-}$subsets, $\mathrm{HBC}$ were separated into two fractions on the basis of HLA-DR antigen density by FACS. The HLA-DR ${ }^{+}$fraction was defined as strongly positive fluorescence intensity (channel 61-254; MAb HLA-DR, > 95\% DR ${ }^{+}$). A typical FACS histogram of pre- and postsort HLA-DR expression is shown in Fig. 2. Although $0-9 \% \mathrm{DR}^{+}$cells were present immediately after sort in the low-density DR fraction, these cells diminished after replating (after $48 \mathrm{~h}$ of culture $0-2 \% \mathrm{DR}^{+}$cells remained in the $\mathrm{DR}^{-}$fraction). Neither conditioned medium from the presort $\mathrm{HBC}$ or postsort $\mathrm{DR}^{+}$fraction added to the $\mathrm{DR}^{-}$fraction nor conditioned medium from the presort $\mathrm{HBC}$ or postsort $\mathrm{DR}^{-}$

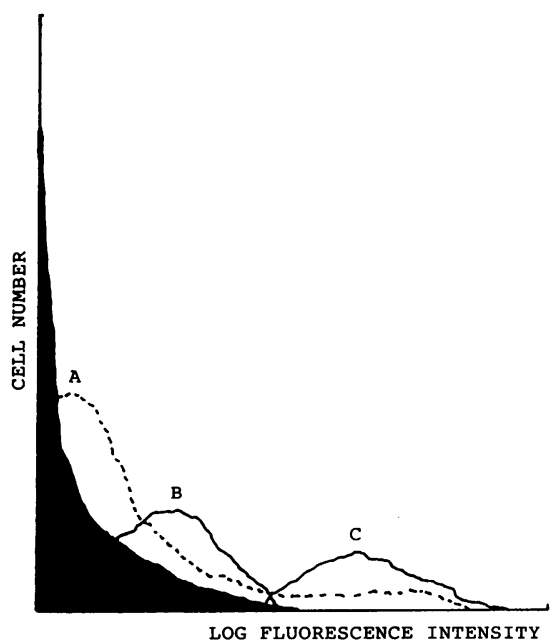

Figure 2. Separation of HBC into high- and low-density HLA-DRpositive cells. $A$, presort fluorescent histogram of HLA-DR using the MAb HLA-DR (23\% of cells are positive); $B$, postsort reanalysis of low-density $\mathrm{DR}$ fraction. Although initially $\mathrm{DR}^{+}$cells were left in fraction B (range of $0-9 \%$ in all cultures determined) these cells were undetectable within 48-72 h. $C$, postsort reanalysis of high-density DR-positive cells $\left(99 \% \mathrm{DR}^{+}\right)$. fraction added to the $\mathrm{DR}^{+}$fraction altered $\mathrm{DR}$ expression in cultures (examined after 1 wk of postsort culture; data not shown). Both $\mathrm{DR}^{+}$and $\mathrm{DR}^{-}$cultures showed viability $>95 \%$ (eosin exclusion) after $1 \mathrm{wk}$ of postsort culture. Whereas remaining $\mathrm{DR}^{+}$cells in the low-density postsort populations rapidly disappeared within $48 \mathrm{~h}$ as detected by immunoperoxidase staining, the percentage of $\mathrm{DR}^{+}$cells, having remained stable for at least $1 \mathrm{wk}$, gradually diminished in the high-density postsort culture after 2-4 wk (a range of 5-40\% reduction in numbers of $\mathrm{DR}^{+}$cells). In addition, the high-density populations showed signs of increasing cell death after 4-6 wk in culture. By contrast, the low-density population remained stable in long-term culture without reappearance of $\mathrm{DR}^{+}$cells when reexamined after 2-4 wk. Nevertheless, reappearance of DR-expressing HBC in these populations at a later stage has not been determined.

A total of four experiments on osteocalcin production by different pre- and postsort HBC populations were undertaken. Fig. 3 illustrates one representative experiment. Osteocalcin was produced by $1,25(\mathrm{OH})_{2} \mathrm{D}_{3}$-stimulated unseparated $\mathrm{HBC}$ as previously reported (11). Both $\mathrm{DR}^{+}$and $\mathrm{DR}^{-}$sorted $\mathrm{HBC}$ produced osteocalcin in a dose-dependent manner when stimulated by $1,25(\mathrm{OH})_{2} \mathrm{D}_{3} 48 \mathrm{~h}$ and similarly $1 \mathrm{wk}$ after cell separation. In the $\mathrm{DR}^{+}$populations HLA-DR and osteocalcin were coexpressed since they were both present in $\geq 95 \%$ of the cells (data not shown).

rIFN $\gamma$ and $1,25(\mathrm{OH})_{2} \mathrm{D}_{3}$ stimulate $\mathrm{HBCHLA}$ class II expression, whereas IL-1, PTH, and calcitonin have no effect alone or with rIFN $\gamma$. To test the influence of osteotropic hormonal factors on HBC HLA-DR and DQ expression six experiments on different $\mathrm{HBC}$ cultures were undertaken. In Table III results of 48-h $\mathrm{HBC}$ stimulation by $(a)$ IIFN $\gamma$ and $(b)$ $1,25(\mathrm{OH})_{2} \mathrm{D}_{3}, \mathrm{PTH}, \mathrm{IL}-1$, and calcitonin with and without rIFN $\gamma$ from two representative experiments are presented. DR expression was assessed in all cases; DQ expression was determined after rIFN $\gamma$ stimulation only. The enhancement of DR expression by $\mathrm{rIFN} \gamma\left(10 \mathrm{U} / \mathrm{ml}\right.$; $\mathrm{DR}^{+} \mathrm{HBC}$ range $40-90 \%, \mathrm{DQ}^{+}$ $\mathrm{HBC}$ range $5-20 \%)$ and $1,25(\mathrm{OH})_{2} \mathrm{D}_{3}\left(10^{-7} \mathrm{M} ; \mathrm{DR}^{+} \mathrm{HBC}\right.$ range $24-50 \%$ ) was blocked by cycloheximide (Table III) suggesting that new protein synthesis was necessary for this alter-

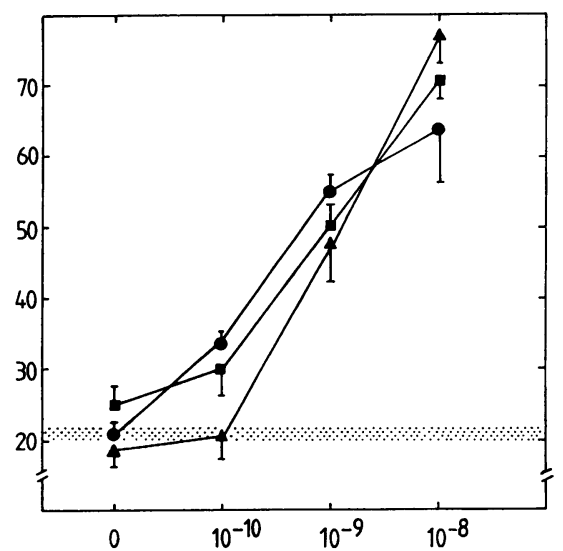

Figure 3. Changes in osteocalcin production (ordinate; $\mathrm{ng} / \mathrm{ml}$ ) into the medium by first-passage unseparated $\operatorname{HBC}(\bullet)$, FACS-separated HLA-DR ${ }^{+}\left(99 \% \mathrm{DR}^{+}\right) \mathrm{HBC}(\triangle)$, and FACS-separated HLA-DR ${ }^{-}(0 \%$ $\left.\mathrm{DR}^{+}\right) \mathrm{HBC}(a)$ in response to $48 \mathrm{~h}$ of treatment with $1,25(\mathrm{OH})_{2} \mathrm{D}_{3}$ (abscissa; $M$ ). The stippled area represents the mean \pm SEM of control. $n=6$; control, cultures without addition of $1,25(\mathrm{OH})_{2} \mathrm{D}_{3}$. 
Table III. Effects of Osteotropic Factors on $H B C H L A-D R$ and $H L A-D Q$ Expression

\begin{tabular}{|c|c|c|c|c|}
\hline \multirow[b]{2}{*}{ Addition } & \multicolumn{2}{|c|}{$\mathrm{DR}^{+} \mathrm{HBC}$} & \multicolumn{2}{|c|}{$\mathrm{DQ}^{+} \mathrm{HBC}$} \\
\hline & Exp. 1 & Exp. 2 & Exp. 1 & Exp. 2 \\
\hline & \multicolumn{2}{|c|}{$\%$} & \multicolumn{2}{|c|}{$\%$} \\
\hline Medium alone & $16 \pm 4$ & $26 \pm 2$ & $7 \pm 1$ & $11 \pm 3$ \\
\hline \multirow{2}{*}{\multicolumn{5}{|c|}{$\begin{array}{c}\operatorname{rIFN} \gamma(U / m l) \\
0.1\end{array}$}} \\
\hline & & & & \\
\hline 1 & $49 \pm 5^{*}$ & $67 \pm 8^{*}$ & $6 \pm 1$ & $17 \pm 5$ \\
\hline 10 & $77 \pm 11^{*}$ & $69 \pm 9 *$ & $6 \pm 2$ & $20 \pm 1^{*}$ \\
\hline 1,000 & $72 \pm 8^{*}$ & $81 \pm 15^{*}$ & $9 \pm 5$ & $20 \pm 6$ \\
\hline $10+$ cycloheximide & $80 \pm 11^{*}$ & ND & $6 \pm 0$ & ND \\
\hline \multirow[t]{3}{*}{$20 \mu \mathrm{g} / \mathrm{ml}$} & $19 \pm 5$ & $29 \pm 6$ & $5 \pm 0$ & $13 \pm 4$ \\
\hline & \multicolumn{4}{|c|}{$\mathrm{DR}^{+} \mathrm{HBC}$} \\
\hline & Withou & rIFN- $\gamma$ & $\begin{array}{l}\text { With } \\
\text { (10 }\end{array}$ & $\begin{array}{l}\mathrm{FN} \gamma \\
\text { (ml) }\end{array}$ \\
\hline \multirow[t]{2}{*}{ Addition } & Exp. 1 & Exp. 2 & Exp. 1 & Exp. 2 \\
\hline & \multicolumn{4}{|c|}{$\%$} \\
\hline \multicolumn{5}{|l|}{$\begin{array}{c}1,25(\mathrm{OH})_{2} \mathrm{D}_{3}(M) \\
10^{-10}\end{array}$} \\
\hline $10^{-9}$ & $14 \pm 4$ & $28 \pm 3$ & $73 \pm 5$ & $79 \pm 9$ \\
\hline $10^{-8}$ & $19 \pm 4$ & $33 \pm 8$ & $90 \pm 3^{\ddagger}$ & $88 \pm 1^{\ddagger}$ \\
\hline $10^{-7}$ & $26 \pm 7$ & ND & $95 \pm 4^{\ddagger}$ & ND \\
\hline $10^{-7}+$ cycloheximide & $45 \pm 4^{\ddagger}$ & $49 \pm 2^{\ddagger}$ & $93 \pm 6^{\ddagger}$ & $90 \pm 3^{\ddagger}$ \\
\hline$(20 \mu \mathrm{g} / \mathrm{ml})$ & $17 \pm 3$ & $24 \pm 1$ & $21 \pm 5$ & $29 \pm 2$ \\
\hline \multicolumn{5}{|l|}{ PTH $(M)$} \\
\hline $10^{-9}$ & $17 \pm 2$ & ND & $75 \pm 7$ & ND \\
\hline $10^{-8}$ & $16 \pm 5$ & $29 \pm 5$ & $70 \pm 7$ & $66 \pm 5$ \\
\hline $10^{-7}$ & $16 \pm 4$ & $23 \pm 2$ & $77 \pm 2$ & $72 \pm 9$ \\
\hline \multicolumn{5}{|l|}{$\mathrm{Il}-1(\mathrm{U} / \mathrm{ml})$} \\
\hline 5 & $19 \pm 7$ & $22 \pm 5$ & $69 \pm 3$ & $65 \pm 13$ \\
\hline 50 & $16 \pm 2$ & $27 \pm 5$ & $77 \pm 11$ & $69 \pm 3$ \\
\hline \multicolumn{5}{|l|}{ Calcitonin $(M)$} \\
\hline $10^{-9}$ & $20 \pm 4$ & $26 \pm 2$ & $74 \pm 2$ & $70 \pm 4$ \\
\hline $10^{-8}$ & $17 \pm 2$ & $22 \pm 5$ & $76 \pm 2$ & $69 \pm 1$ \\
\hline
\end{tabular}

FACS analysis of first-passage HBC after incubation for $48 \mathrm{~h}$ with appropriate osteotropic factor(s). Results expressed as mean of triplicate \pm SEM.

* Significantly different from control (medium alone), $P<0.05$.

* Significantly different from control (rIFN $\gamma$ alone), $P<0.05$. ND, not determined.

ation. In all experiments, $1,25(\mathrm{OH})_{2} \mathrm{D}_{3}\left(10^{-9}\right.$ to $\left.10^{-7} \mathrm{M}\right)$ enhanced the rIFN $\gamma$-stimulated DR mean fluorescence intensity (data not shown). When added to postsort high- and low-density DR HBC populations, IFN $\gamma$ enhanced DR expression in both systems, indicating a stimulatory action on both $\mathrm{DR}^{+}$as well as $\mathrm{DR}^{-}$HBC (data not shown).

\section{Discussion}

The demonstration of a constitutive, stable expression of HLA class II determinants by cells derived from normal trabecular bone surfaces and kept in long-term culture suggests the possi- bility of an in situ phenomenon. However, soluble factors in the culture medium that might alter HBC HLA-DR expression were not found in conditioned media from either unseparated $\mathrm{HBC}$ or $\mathrm{DR}^{+}$and $\mathrm{DR}^{-}$separated fractions. Although expression of class II antigens by $29-46 \%$ of isolated normal rabbit chondrocytes has been reported (17), normal human connective tissue cells do not express HLA class II antigens constitutively, including human fibroblasts (18) and human chondrocytes (19). This raised the question whether HLA class II-positive marrow hemopoietic cells might be present in our human bone cell cultures. However, this appears unlikely since morphologically HBC were homogeneous and fibroblast-like, and HBC lacked monocyte/macrophage-, pan-T and $B$ lymphocyte, and NK cell markers. In addition, separated $\mathrm{DR}^{+}$and $\mathrm{DR}^{-} \mathrm{HBC}$ both produced the bone protein, osteocalcin, when stimulated by $1,25(\mathrm{OH})_{2} \mathrm{D}_{3}$. So far, osteocalcin has been reported to be produced by osteoblasts only (16), suggesting an osteoblast-like phenotype of $\mathrm{DR}^{+}$as well as $\mathrm{DR}^{-} \mathrm{HBC}$. Nevertheless, the presence in our cultures of dendritic cells which express high levels of both HLA-DR and -DQ (20) has not been excluded.

The separated high- and low-density DR-expressing populations did not revert back to the original distribution after 4 wk of postsort culture. On the contrary, the $\mathrm{DR}^{+}$subset rapidly disappeared from the low-density fraction and after 2 wks were reduced in the high-density fraction. Possibly, the $\mathrm{DR}^{+}$subset may be more fragile than their $\mathrm{DR}^{-}$counterpart and thus damaged selectively during the FACS procedures. Alternatively, the $\mathrm{DR}^{+}$phenotype may depend upon factors expressed within the unseparated population only.

The observation that IFN $\gamma$ stimulates HBC HLA-DR expression is in accordance with data on other connective tissue cells including human dermal fibroblasts (18), human synovial fibroblasts (21), and human chondrocytes (19). Although IFN $\gamma$ induces HLA-DQ in certain cells including monocytes (22), this cytokine has been reported to induce only low levels or no HLA-DQ determinants on connective tissue cells such as synovial fibroblasts (23), chondrocytes (19), and, as in this study, HBC.

In contrast with two other major bone resorbing factors, PTH $\left(10^{-9}\right.$ to $\left.10^{-7} \mathrm{M}\right)$ and IL-1 $(5-50 \mathrm{U} / \mathrm{ml}), 1,25(\mathrm{OH})_{2} \mathrm{D}_{3}$ $\left(10^{-9}\right.$ to $\left.10^{-7} \mathrm{M}\right)$ enhanced IFN $\gamma$-stimulated HBC HLA-DR expression and at high supraphysiological levels $\left(10^{-7} \mathrm{M}\right)$ stimulated DR expression by itself. Similar findings have been reported regarding the Ia-negative murine myelomonocytic cell line WEHI-3 (24). In this study $1,25(\mathrm{OH})_{2} \mathrm{D}_{3}\left(10^{-10}\right.$ to $10^{-8}$ M) was found to enhance IFN $\gamma$-induced Ia expression. By contrast, using a HLA class II-positive melanoma cell line, Carrington et al. (25) found a dose-dependent inhibition of DR $\alpha$ mRNA by $1,25(\mathrm{OH})_{2} \mathrm{D}_{3}\left(10^{-12}\right.$ to $\left.10^{-8} \mathrm{M}\right)$. In other class II-positive cell lines, however, class II molecules were not altered by $1,25(\mathrm{OH})_{2} \mathrm{D}_{3}(26)$. Factors affecting class II expression in opposite directions, released during $1,25(\mathrm{OH})_{2} \mathrm{D}_{3}$ stimulation, might explain the differences between the cell lines. Thus, $1,25(\mathrm{OH})_{2} \mathrm{D}_{3}$ has been reported to stimulate production of IFN $\gamma$ by $\mathrm{T}$ lymphocytes in vitro (26). To test the possibilities that $1,25(\mathrm{OH})_{2} \mathrm{D}_{3}(a)$ stimulates factors, such as IFN $\gamma$, which induce class II expression in the HBC cultures and/or $(b)$ enhances the responsiveness of HBC to IFN $\gamma$ by altering HBC proliferation, further studies are needed. Calcitonin, which inhibits the bone-resorbing activity of osteoclasts (27) and also may affect osteoblasts (28), did not alter HBC DR expression 
$\left(10^{-9}\right.$ to $\left.10^{-8} \mathrm{M}\right)$ suggesting that a change in HBC DR levels is not involved in calcitonin-mediated osteoclast inhibition.

We suggest that HLA class II-positive bone surface cells of the osteoblast lineage may play a role in local $\mathrm{T}$ lymphocyte activation including release of osteoclast-activating $T$ lymphocyte-derived cytokines. Thus, studies are in progress on the abilities of $\mathrm{HBC}$ to stimulate in mixed lymphocyte reaction (MLR) and to present antigen (29). Since the presence of IL-1 may be important for these activities the recent finding of constitutive IL-1 production by HBC (30) is of interest. Enhancement of HBC HLA class II expression by IFN $\gamma$ and $1,25(\mathrm{OH})_{2} \mathrm{D}_{3}$ could be involved in the osteotropic activity of these factors.

\section{Acknowledgments}

We thank Mr. J. Lowry and Mr. C. Day for expert technical assistance. We are grateful to the following for financial support: The British Council; Glaxo Group Research, Greenford, U.K.; and the Danish Rheumatism Association (Gigtforeningen).

\section{References}

1. Vaes, G. 1988. Cellular biology and biochemical mechanism of bone resorption. Clin. Orthop. Relat. Res. 231:239-271.

2. Dewhirst, F. E., P. P. Stashenko, J. E. Mole, and T. Tsurumachi. 1985. Purification and partial sequence of human osteoclast-activating factor: identity with interleukin $1 \beta . J$. Immunol. 135:2562-2568.

3. Bertolini, D. R., G. E. Nedwin, T. S. Bringman, D. D. Smith, and G. R. Mundy. 1986. Stimulation of bone resorption and inhibition of bone formation in vitro by human tumor necrosis factors. Nature (Lond.). 319:516-519.

4. Roodman G. D., N. Takahashi, A. Bird, and G. R. Mundy. 1987. Tumor necrosis factor alpha (TNF) stimulates formation of osteoclast-like cells (OCL) in long term human bone marrow cultures by stimulating production of interleukin-1 (Il-1). Clin. Res. 35:515a. (Abstr.)

5. Thomson, B. M., J. Saklatvala, and T. J. Chambers. 1986. Osteoblasts mediate interleukin 1 stimulation of bone resorption by rat osteoclasts. J. Exp. Med. 164:104-111.

6. Thomson, B. M., G. R. Mundy, and T. J. Chambers. 1987. Tumor necrosis factor $\alpha$ and $\beta$ induce osteoblastic cells to stimulate osteoclastic bone resorption. J. Immunol. 138:775-779.

7. Gowen, M., G. E. Nedwin, and G. R. Mundy. 1986. Preferential inhibition of cytokine-stimulated bone resorption by recombinant interferon gamma. J. Bone Miner. Res. 1:469-473.

8. Royer, H. D., and E. L. Reinherz. 1987. T lymphocytes: Ontogeny, function, and relevance to clinical disorders. N. Engl. J. Med. 317:1136-1142.

9. Dinarello, C. A., and J. W. Mier. 1987. Lymphokines. N. Engl. J. Med. 317:939-945.

10. Rose, M. L. 1985. Immunoregulation of MHC antigen expression. Immunol. Today. 6:297-298.

11. Beresford, J. N., J. A. Gallagher, J. W. Poser, and R. G. G. Russell. 1984. Production of osteocalcin by human bone cells in vitro: effects of $1,25(\mathrm{OH})_{2} \mathrm{D}_{3}, 24,25(\mathrm{OH})_{2} \mathrm{D}_{3}, \mathrm{PTH}$ and glucocorticoids. Metab. Bone Dis. Relat. Res. 5:229-235.

12. Bozdech, M. J., and D. F. Bainton. 1981. Identification of $\alpha$-naphthyl butyrate esterase as a plasma membrane ectoenzyme of monocytes and as a discrete intracellular membrane-bounded organel in lymphocytes. J. Exp. Med. 153:182-195.

13. Jacobs, D. M., and D. C. Morrison. 1977. Inhibition of the mitogenic response to lipopolysaccharide (LPS) in mouse spleen cells by polymyxin B. J. Immunol. 118:21-25.

14. Horan, P. K., and M. R. Loken. 1985. A practical guide for the use of flow systems. In Flow Cytometry: Instrumentation and Data Analysis. M. A. van Dilla, P. N. Dean, O. D. Laerum, and M. R. Melamed, editors. Academic Press, Inc., New York. 259-288.

15. Ashton, B. A., F. Abdullah, J. Cave, M. Williamson, B. C. Sykes, M. Couch, and J. W. Poser. 1985. Characterization of cells with high alkaline phosphatase activity derived from human bone and marrow: preliminary assessment of their osteogenicity. Bone. 6:313319.

16. Price, P. A. 1983. Osteocalcin. In Bone and Mineral Research Annual. Volume 1. W. A. Peck, editor. Excerpta Medica, Amsterdam. 157-190.

17. Tiku, M. L., S. Liu, C. W. Weaver, M. Teodorescu, and J. L. Skosey. 1985. Class II histocompatibility antigen-mediated immunologic function of normal articular chondrocytes. J. Immunol. 135:2923-2928.

18. Geppert, T. D., and P. E. Lipsky. 1985. Antigen presentation by interferon- $\gamma$-treated endothelial cells and fibroblasts: differential ability to function as antigen-presenting cells despite comparable Ia expression. J. Immunol. 135:3750-3762.

19. Jahn, B., G. R. Burmester, H. Schmid, G. Weseloh, P. Rohwer, and J. R. Kalden. 1987. Changes in cell surface antigen expression on human articular chondrocytes induced by gamma-interferon. Arthritis Rheum. 30:64-74.

20. Knight, S. C., P. Fryer, S. Griffith, and B. Harding. 1987. Class II histocompability antigens on human dendritic cells. Immunology. 61:21-24.

21. Amento, E. P., A. K. Bhan, K. G. McCullagh, and S. M. Krane. 1985. Influence of gamma interferon on synovial fibroblast-like cells. Ia induction and inhibition of collagen synthesis. J. Clin. Invest. 76:837-848.

22. Gonwa, T. A., and J. D. Stobo. 1984. Differential expression of Ia molecules by human monocytes. J. Clin. Invest. 74:859-866.

23. Burmester, G. R., B. Jahn, P. Rohwer, J. Zacher, R. J. Winchester, and J. R. Kalden. 1987. Differential expression of Ia antigens by rheumatoid synovial lining cells. J. Clin. Invest. 80:595-694.

24. Morel, P. A., S. C. Manolagas, D. M. Provvedini, D. R. Wegmann, and J. M. Chiller. 1986. Interferon- $\gamma$-induced Ia expression in WEHI-3 cells is enhanced by the presence of 1,25-dihydroxyvitamin $\mathrm{D}_{3}$. J. Immunol. 136:2181-2186.

25. Carrington, M. N., B. Tharp-Hiltbold, J. Knoth, and F. E. Ward. 1988. 1,25-dihydroxyvitamin $D_{3}$ decreases expression of HLA class II molecules in a melanoma cell line. J. Immunol. 140:40134018.

26. Manolagas, S. C., D. M. Provvedini, D. J. Young, and C. D. Tsoukas. 1988. At physiological concentrations 1,25-dihydroxyvitamin $D_{3}$ acts directly on $T$ cells to stimulate $\gamma$-interferon. $J$. Bone Miner. Res. 3:S82. (Abstr.)

27. Friedman, J., and L. G. Raisz. 1965. Thyrocalcitonin: inhibitor of bone resorption in tissue culture. Science (Wash. DC). 150:14651467.

28. Farley, J., N. M. Tarbaux, S. L. Hall, T. A. Linkhart, and D. J. Baylink. 1988. The anti-bone-resorptive agent calcitonin also acts in vitro to directly increase bone formation and bone cell proliferation. Endocrinology. 123:159-167.

29. Skjødt, H., T. Møller, and S. Freiesleben. 1989. Human osteoblast-like cells expressing MHC class II determinants stimulate allogeneic and autologous peripheral blood mononuclear cells and function as antigen presenting cells. Immunology. 68:416-420.

30. Hughes, D. E., M. Gowen, R. G. G. Russell. 1988. Interleukin 1 as a paracrine factor in bone: Effects on osteoclast-like cell formation and production by osteoblast-like cells. J. Bone Miner. Res. 3:S196. (Abstr.) 